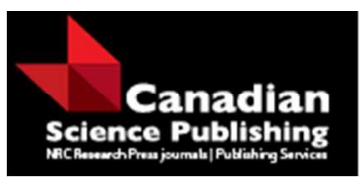

Canadian Journal of Forest Research

Revue canadienne de recherche forestière

\title{
Carbon isotope discrimination by Picea glauca and Populus tremuloides is related to the topographic depth to water index and rainfall
}

\begin{tabular}{|r|l|}
\hline Journal: & Canadian Journal of Forest Research \\
\hline Manuscript ID & cjfr-2015-0491.R2 \\
\hline Manuscript Type: & Article \\
\hline Date Submitted by the Author: & $29-J u n-2016$ \\
\hline Keymote List of Authors: & $\begin{array}{l}\text { Oltean, Gabriel; University of Alberta, Renewable Resources } \\
\text { Comeau, Philip; University of Alberta, Renewable Resources } \\
\text { White, Barry; Alberta Agriculture and Forestry, Forest Management Branch }\end{array}$ \\
\hline & $\begin{array}{l}\text { depth-to-water, topographic index, carbon isotope ratio, water stress, soil } \\
\text { properties }\end{array}$ \\
\hline
\end{tabular}

\section{SCHOLARONE \\ Manuscripts}


$1 \quad$ Title

2 Carbon isotope discrimination by Picea glauca and Populus tremuloides is related to the

3 topographic depth to water index and rainfall

\section{Author names and affiliations}

5 Gabriel S. Oltean ${ }^{\mathrm{a}}$ - oltean@ualberta.ca

$6 \quad$ Philip G. Comeau ${ }^{\mathrm{a}}$ - pcomeau@ualberta.ca

${ }^{\mathrm{a} D e p a r t m e n t ~ o f ~ R e n e w a b l e ~ R e s o u r c e s, ~ U n i v e r s i t y ~ o f ~ A l b e r t a, ~} 751$ General Services Building, Edmonton, AB T6G 2H1, Canada

$9 \quad$ Barry White ${ }^{\text {b }}$ - barry.white@gov.ab.ca

${ }^{\mathrm{b}}$ Forest Management Branch, Alberta Environment and Sustainable Resource

Development, Edmonton, AB T5K 2M4, Canada

\section{Corresponding author}

12 Gabriel S. Oltean - email: oltean@ualberta.ca; tel: (+4) 0759089430

13 Department of Renewable Resources, University of Alberta, 751 General Services Building, Edmonton, AB T6G 2H1, Canada 


\section{Abstract}

16 Carbon isotope ratio $\left(\delta^{13} \mathrm{C}\right)$ has been used as an indicator of water stress since plants

17 discriminate less against ${ }^{13} \mathrm{C}$ when under stress. The depth-to-water (DTW) topographic index

18 provides and estimation of soil moisture based on topographic position and other characteristics

19 of a site. To evaluate whether DTW and carbon isotope discrimination were related and to

20 determine if these relationships are influenced by climate we sampled three time periods, which

21 differed in the amount of annual precipitation (MAP), from tree cores collected from 42

22 trembling aspen and 43 white spruce trees growing along DTW gradients at two locations in

23 central Alberta, Canada. Increasing MAP lead to lower $\delta^{13} \mathrm{C}$, indicating less drought stress as

24 water availability increases, while $\delta^{13} \mathrm{C}$ increased with DTW up to a threshold value, after which

25 the relationship levelled off suggesting that higher DTW values represent stress inducing soil

26 conditions. DTW and MAP were then combined into models (aspen $\mathrm{R}^{2}=0.72$, spruce $\mathrm{R}^{2}=0.44$ )

27 that could be used to delineate drought prone areas during periods of low MAP. Tree height and

28 diameter were also related with DTW suggesting a functional relationship between an index

29 capturing soil properties and tree size. Our results demonstrate the potential to use the DTW

30 index as a measure of site conditions and to predict stand level responses.

31 Keywords: depth to water, topographic index, carbon isotope ratio, water stress, soil properties. 


\section{Introduction}

Water stress in woody plants is recorded in the carbon isotope ratio of their leaves and

34 wood. Discrimination against the heavier stable isotope of carbon (i.e., ${ }^{13} \mathrm{C}$ ) can occur during the

35 diffusion of atmospheric $\mathrm{CO}_{2}$ through stomata and at the site of carbon fixation by RuBisCO

36 (Berry 1988). The strength of discrimination is measured by the ${ }^{13} \mathrm{C} /{ }^{12} \mathrm{C}$ ratio of tree tissues

37 relative to the isotopic composition of Pee Dee Belemnite material and is denoted $\delta_{\text {sample }}^{13}$

38 (Farquhar et al. 1982). A more informative definition of $\delta^{13} \mathrm{C}$ is

$$
\delta^{13} \mathrm{C}=\delta_{\mathrm{air}}^{13}-a-(b-a) c_{i} / c_{a}
$$

39 where $\delta_{\text {air }}^{13}$ represents the carbon isotope ratio of the air surrounding the leaf, $c_{a}$ and $c_{i}$ are the

$40 \mathrm{CO}_{2}$ concentrations of the atmosphere and leaf intercellular spaces (Francey and Farquhar 1982).

41 The constant $a$ is the diffusivity of $\mathrm{CO}_{2}$ in air with a value of $4.4 \%$, and $b$ is the isotope

42 fractionation of RuBisCO considered to be approximately $30 \%$. With $\delta_{\text {air }}^{13}$ equal to about $-8 \%$,

43 the value of $\delta^{13} \mathrm{C}$ is controlled by the $c_{i} / c_{a}$ ratio representing photosynthesis rate and stomatal

44 conductance. Therefore, $\delta^{13}$ Creflects the effects of environmental factors on the $c_{i} / c_{a}$ ratio

45 (Francey and Farquhar 1982). Environmental conditions limiting assimilation rates (e.g., low

46 light intensities) will increase $c_{i} / c_{a}$ and reduce $\delta^{13} \mathrm{C}$, whereas factors reducing stomatal

47 conductance (e.g., water stress, strong vapour pressure deficits) will lower $c_{i} / c_{a}$ and increase

$48 \delta^{13} \mathrm{C}$ (Farquhar et al. 1989). Topography that creates xeric conditions (e.g., ridges, steep slopes)

49 was consistently associated with high $\delta^{13} \mathrm{C}$ in leaves of temperate deciduous trees (Garten and

50 Taylor 1992), however small topographic features (e.g., gullies) did not influence wood $\delta^{13} \mathrm{C}$ in

51 Sequoia sempervirens (D. Don) (Roden et al. 2011). In contrast to leaves, wood $\delta^{13} \mathrm{C}$ has the 
52 advantage of integrating the large spatial variation of leaf $\delta^{13} \mathrm{C}$ within a crown (Leavitt and Long

53 1986; Waring and Silvester 1994), as well as capturing environmental conditions over multiple

54 seasons.

The increasing availability of remotely-sensed accurate digital elevation models (DEM)

56 allows the collection of valuable up-to-date information about the topography of large forested

57 areas with relatively low costs (Moore et al. 1991). Simple topographic indices such as slope,

58 aspect or profile curvature have been used to predict soil $\mathrm{pH}$ and texture (Moore et al. 1993),

59 which are also related to landscape position (Brubaker et al. 1993), whereas Allen et al. (1991)

60 combined topographic position, potential solar radiation and aspect into a topographic moisture

61 index to predict species composition. The most widely used complex terrain index is the

62 topographic wetness index (TWI), defined as the logarithm of the ratio of upslope area to local

63 slope (Beven and Kirkby 1979). TWI has been used to map the extent of water-saturated areas

64 (Burt and Butcher 1985; Guntner et al. 2004) or predict detailed soil properties (e.g., thickness,

$65 \mathrm{pH}$ and C:N ratio of the organic horizon) in the Swedish boreal forest (Seibert et al. 2007). These

66 and other authors indicate that different algorithms must be used in different landscapes or for

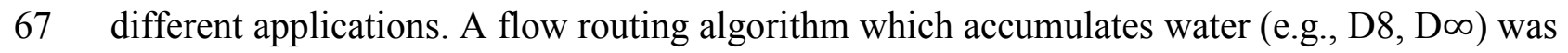

68 recommended to delineate flow channels (Sorensen et al. 2006; Tarboton 1997), whereas more

69 distributed flow algorithms (e.g., MD $\infty$, FD8) are better suited for mapping of broad features

70 such as species composition (Kopecky and Cizkova 2010).

71 The depth-to-water (DTW) index integrates the horizontal and vertical distance from a

72 given point in the landscape to the nearest flow channel. The latter is defined by the choice of a

73 flow initiation area (Murphy et al. 2007). The DTW index was found to be superior to TWI in

74 mapping of wet areas in the boreal forest since TWI is strongly dependent on the upslope area, 
75 while local downslope topography is a major determinant of soil moisture conditions (Murphy et

76 al. 2009). Changing the flow initiation area affects the extent of the flow channel network,

77 adapting the DTW index to various landscape configurations and geologies, and temporal

78 changes in soil moisture (e.g., wet or dry years). DTW calculated at a large flow initiation area

79 (i.e., $>8$ ha) performed better on terrain with strong topography and high hydraulic conductivity

80 while a smaller threshold area (i.e., 1 ha) was suggested for an area with low topography and

81 poor drainage (Ågren et al. 2014). Field observations in the boreal forest of Alberta indicated

82 that flow channels delineated at a flow initiation area of 4 ha correspond to streams with

83 permanent or intermittent flow representing soil conditions late in the season (White et al. 2012).

84 Further, a companion study showed that DTW is related to the depth to mottles in the soil and to

85 drainage regime, which allowed us to develop a model of soil moisture based on DTW and other

86 topographic indices (Oltean et al. 2016). Further testing of the DTW index is needed to evaluate

87 its capabilities and limitations in areas with contrasting topography.

Depth-to-water rasters are available for extensive areas in Alberta and New Brunswick

89 where DTW was shown to perform better than TWI (Murphy et al. 2009; Murphy et al. 2011).

90 Thus, a deeper understanding of the ecological significance of DTW values, as well as its

91 potential applications and limitations to the use of this index are needed. The objectives of the

92 present study were (1) to evaluate the relationship between DTW and $\delta^{13} \mathrm{C},(2)$ to explore a

93 gradient of flow initiation area thresholds in contrasting terrains, and (3) to assess the association

94 between DTW and tree size (i.e., height and diameter). We expected that DTW would be related

95 with $\delta^{13} \mathrm{C}$ and tree size but will present a threshold after which its influence diminishes, and that

96 optimal flow initiation area would depend on terrain morphology. 


\section{Materials and methods}

98

99

100

101

102

103

104

105

106

107

108

109

110

111

112

113

114 whereas the spruce stand had been planted in May 1993 with 1 year old stock and was sampled

115 in late-summer of 2014.

\section{Sample collection and preparation}

117

We used existing DEM and DTW rasters for the two sites to select locations that covered

118 a wide range of topographic conditions and DTW values (Fig. 1). We navigated to each point 
119 and then selected a dominant tree, for which we measured the diameter at breast height (dbh),

120 total height, height to live crown, crown radii on the northern and western directions, and made

121 notes about the conditions in which the trees were growing (e.g., edge tree, open grown). A total

122 of 42 trembling aspen and 43 white spruce trees were selected and their locations recorded with a

123 Trimble GeoExplorer 6000 series GeoXT handheld device (Trimble, Los Altos, California) with

124 GNSS capabilities ensuring sub-meter accuracy for $78 \%$ of the aspen and $87 \%$ of the spruce tree

125 positions. The crown measurements were used to calculate the volume, projected and surface

126 area of the crowns, which were assumed to be paraboloids for the aspen and conical for the

127 spruce trees.

From each tree we collected two cores from the north and south facing side of the stem as

129 recommended by Leavitt and Long (1984). The cores were cleaned and carefully divided into

130 three periods selected based on the annual precipitation relative to the 30 -year $(1981-2010)$

131 normals. In order to have a reasonable amount of wood to analyse for carbon isotopes, we

132 identified two to four years that received either more or less rainfall relative to the climate

133 normals, without fixing the number of years. For the aspen site we selected the $1999-2003$ and

$1342008-2010$ as dry and $2004-2007$ as wet periods, while the periods $2002-2003$ and $2008-$

1352009 were dry and $2011-2012$ was relatively wet at the spruce site (Fig. 2). The $2004-2007$

136 period at the aspen site included one dry season but we did not remove it because its effect was

137 mitigated by the large amount of precipitation in the following year. For each period and species,

138 the sections from the north and south core were both placed in a vial and dried in an oven at 70

$139{ }^{\circ} \mathrm{C}$ for 48 hours. The dried wood samples were finely ground with a Retsch MM 200 ball grinder

140 (Retsch, Dusseldorf, Germany) to ensure sample homogeneity, and then analyzed for their

141 isotopic composition using a mass spectrometer at the Natural Resources Analytical Laboratory 
142 (University of Alberta, Edmonton, AB). We used wood for our isotopic analyses since Walia et 143 al. (2010) found that the $\delta^{13} \mathrm{C}$ of whole wood remains constant even if the ratio of lignin to 144 holocellulose changes.

145 The Depth-to-Water index

146 The depth-to-water index is defined as the cumulative slope along the least cost path from 147 any cell in the landscape to the nearest flow channel (Murphy et al. 2007). The measurement unit 148 for DTW is meters and is calculated as

$$
D T W=\left[\sum \frac{d z_{i}}{d x_{i}} a\right] x_{c}(m),
$$

149 where $d z_{i}$ and $d x_{i}$ are the vertical and horizontal distance between two cells, $a$ is a constant equal

150 to 1 if the path is parallel to the cell edge or $\sqrt{2}$ if the cells are connected across the diagonal, and

$151 x_{c}$ is the size of the raster cell (i.e., $1 \mathrm{~m}$ ). Thus, a cell farther from the channel or at a higher

152 elevation will receive a large DTW value indicating the weak hydrological connection between

153 that cell and its source of water (Murphy et al. 2009). DTW was calculated using a digital

154 elevation model derived from an airborne LiDAR (Light Detection and Ranging) point cloud

155 with 0.5 to 3 points per square meter and vertical accuracy of $30 \mathrm{~cm}$. False depressions and other

156 artifacts that artificially obstruct water flow were removed from the $1 \mathrm{~m}$ resolution DEM, and

157 flow direction based on the slope to the neighbouring cells was determined for each cell. Flow

158 accumulation (FA) area, defined as the upslope area draining to each cell, was calculated using

159 the highly convergent D8 flow routing algorithm which directs flow to the adjacent cell with the

160 steepest slope (O'Callaghan and Mark 1984). The flow direction and FA rasters were used to

161 determine the cells delineating the flow channels, which receive a DTW value of $0 \mathrm{~m}$. Flow

162 initiation areas of $0.5,1,2,4,8,12$ and 16 ha were used as starting points for the flow channels, 
163 with a new DTW raster being calculated for each threshold.

\section{Statistical analysis}

165 To address the first two objectives we used $\delta^{13} \mathrm{C}$ as the dependent variable and modeled

166 it as a function of DTW, FA and slope averaged over a circular plot centered on the tree and with

167 a radius of $3 \mathrm{~m}$. Preliminary analyses did not show differences between radii of 1, 3, 5, 7.5 and

$16810 \mathrm{~m}$, thus the selected radius was consistent with the accuracy of the tree locations. Since the

169 conditions in which tree crowns develop has strong effects on carbon isotope discrimination

170 (Leavitt 1993), we first tested the $\delta^{13} \mathrm{C}$ difference between trees growing in a closed canopy and

171 those that were in open conditions or at stand edge. Values of $\delta^{13} \mathrm{C}$ in trees exposed to more

172 radiation and stronger vapour pressure deficits were significantly higher for both aspen (-26.08

$173>-26.36, P=0.0468)$ and spruce $(-25.47>-26.15, P<0.0001)$, thus the open-grown and stand

174 edge trees were removed prior to any analyses of $\delta^{13} \mathrm{C}$ data. This reduced our sample sizes to 30

175 aspen and 26 spruce trees.

We began our analysis with a linear mixed-effects model between $\delta^{13} \mathrm{C}$ and mean annual

177 precipitation (MAP) for each time period with random effects for the intercept, which induces a

178 compound symmetry correlation structure for the $\delta^{13} \mathrm{C}$ measurements made on the same tree.

179 Likelihood ratio tests, recommended to select the optimal structure for the random effects

180 (Pinheiro and Bates 2000), indicated that a random effect for the slope was not needed. Since

181 each tree was allowed to have a different intercept, the conditional modes of the random effects

182 represented the variation of $\delta^{13} \mathrm{C}$ between tree locations. Therefore, the null hypothesis of no

183 relationship between $\delta^{13} \mathrm{C}$ and the topographic indices (i.e., DTW, FA slope) was tested using

184 the conditional modes. Moreover, this approach allowed us to combine the three $\delta^{13} \mathrm{C}$ values per 
185 tree into a single number. The relation between $\delta^{13} \mathrm{C}$ and DTW, calculated at the seven flow 186 initiation areas, was modeled with an asymptotic function of the form

$$
\mathrm{y}(\mathrm{x})=a+(b-a) \exp [-\exp (c) \mathrm{x}]
$$

187 where $a$ is the asymptote as $x \rightarrow \infty$ and $b$ is the value of $y$ at $x=0$. The expression $\exp (c)$ is the 188 rate parameter and is used in this form to ensure that the model approaches an asymptote. This 189 curve becomes a flat line when $\exp (c)=0$, indicating no relationship between the two variables. 190 A significance test for the estimate of $c$ cannot be devised since $\exp (0)=1$ and $\exp (c) \rightarrow 0$ as $c$ 191 becomes more negative $(\exp (-2)=0.14)$. Instead, we used the coefficient of determination 192 (i.e., $\mathrm{R}^{2}$ ) to compare among the different flow initiation areas while providing the estimate of $c$ 193 for the relevant models to judge significance. We selected this asymptotic function based on an 194 expected functional relationship between $\delta^{13} \mathrm{C}$ and DTW (i.e., $\delta^{13} \mathrm{C}$ is not influenced by large 195 DTW values), which was supported by empirical evidence. Simple linear regression was used to 196 test the association between the conditional modes of the random effects and FA and slope. Once the strongest predictor was selected, we introduced it as a covariate in the initial 198 mixed model which included only MAP. In this updated model formulation, the random effect

199 for the intercept was removed since that variability was now explained by the topographic index 200 (Pinheiro and Bates 1995). Autocorrelation between the three $\delta^{13} \mathrm{C}$ measurements made on the 201 same tree was accounted for with a general correlation structure found most suitable using 202 likelihood ratio tests (Pinheiro and Bates 2000). This correlation model is more parameter 203 expensive but our short time series (i.e., 3 periods) introduced only two extra parameters over a 204 first order autoregressive model suggested by Monserud and Marshall (2001) while allowing for 205 greater flexibility. Furthermore, their study focused on a time-series analysis of $\delta^{13} \mathrm{C}$ much 206 longer than ours (i.e., 90 years) which made an autoregressive model necessary. Residual plots 
207 and the Shapiro-Wilk normality test were used to assess model fit and the validity of the

208 assumptions imposed on the models. Equation 1 was also used to model the relationship between

209 tree size and the topographic indices but a correlation structure or random effects were not

210 necessary since the data did not present a hierarchical structure with multiple measurements on

211 the same individual. We applied the same modeling approach to both aspen and spruce. The

212 parameters of the mixed-effects models were estimated using the method of maximum likelihood

213 implemented in the nlme library v. 3.1-120 (Pinheiro et al. 2015) within the R environment for

214 statistical modeling v. 3.2.0 (R Core Team 2015).

$215 \quad$ Results

216 Annual precipitation and $\boldsymbol{\delta}^{\mathbf{1 3}} \boldsymbol{C}$

217 Carbon isotope ratio was negatively related to mean annual precipitation for both aspen

218 and spruce (Fig. 3). The linear mixed-effects model fit for each species had the form

$$
\delta^{13} \mathrm{C}_{\mathrm{i}, \mathrm{t}}=\left(\beta_{0}+b_{i}\right)+\beta_{1} \mathrm{MAP}+\varepsilon_{i, t},
$$

219 where $\delta^{13} \mathrm{C}$ was the carbon isotope ratio for tree $i$ at period $t, \beta_{0}$ and $\beta_{1}$ were the intercept and 220 slope, respectively. The slope was fixed but $b_{i}$ represented the deviations of the intercept among

221 trees, considered to be independent and identically distributed (i.i.d.) as $b_{i} \sim N\left(0, \sigma_{b}^{2}\right)$. The errors

222 were also considered i.i.d. as $\varepsilon_{i, t} \sim N\left(0, \sigma^{2}\right)$. The variation between trees $\left(\sigma_{b}^{2}\right)$ was larger than the 223 unexplained variability $\left(\sigma^{2}\right)$ in the case of both species (Fig. 3). Aspen had $\sigma_{b}=0.48$ and $\sigma=$

2240.37 while spruce had $\sigma_{b}=0.58$ and $\sigma=0.52$. The mean $\delta^{13} \mathrm{C}$ value for aspen $(-26.36)$ was lower 225 than that of spruce $(-26.15)$, but this difference diminished as annual precipitation decreased due 226 to the more negative slope for aspen $\left(\beta_{1}=-0.0047, P<0.0001\right)$ than for spruce $\left(\beta_{1}=-0.0016, P\right.$ 
$227=0.0008)$. The intercept varied about $2 \%$ o between trees, from -27.14 to -25.18 for aspen and 228 from -26.85 to -24.95 for spruce.

229 The depth-to-water index and $\delta^{13} C$

230 The conditional modes $\left(b_{i}\right)$ of the random effects for the intercept in Eq. 2 were related to

231 DTW (Fig. 4) based on a flow initiation area of 1 ha for aspen $\left(\mathrm{R}^{2}=0.42\right)$ and 16 ha for spruce

$232\left(\mathrm{R}^{2}=0.16\right)$. The corresponding estimates of the rate parameter in Eq. 1 were $\exp (2.297)=$

2339.944 for aspen and $\exp (-2.193)=0.112$ in the case of spruce. Increasing or decreasing flow

234 initiation area at the aspen site resulted in a gradual decline in the strength of the relationship,

235 with threshold areas of 8,12 and 16 ha providing similar results $\left(\mathrm{R}^{2}=0.107\right.$, Table 2$)$. In the

236 case of spruce, the coefficients of determination remained below those for aspen while following

237 a pattern of gradual increase with larger flow initiation areas, reaching a plateau at catchment

238 areas of 12 and 16 ha (Table 2). Flow accumulation and local slope were not significantly related

239 with the conditional modes $\left(b_{i}\right)$ of the random effects $(P>0.2500)$, yielding weak relationships

$240 \quad\left(R^{2}<0.047\right)$ for both species.

241 The strongest predictor from Table 2 (boldfaced values) was incorporated into Eq. 2 to

242 obtain a model that combines climate and topography to explain variation in $\delta^{13} \mathrm{C}$, for each

243 species (Fig. 5). The two models thus obtained can be expressed as

(Eq. 3)

$$
\delta^{13} \mathrm{C}_{\mathrm{i}, \mathrm{t}}=\beta_{1}+\left(\beta_{2}-\beta_{1}\right) \exp \left(-\exp \left(\beta_{3}\right) \mathrm{DTW}\right)+\beta_{4} \mathrm{MAP}+\varepsilon_{i, t},
$$

244 where $\delta^{13} \mathrm{C}$ was the carbon isotope ratio for tree $i$ at period $t ., \beta_{1}$ was the asymptote, $\beta_{2}$ the value

245 of $\delta^{13} \mathrm{C}$ at DTW of $0 \mathrm{~m}, \exp \left(\beta_{3}\right)$ the rate parameter, and $\beta_{4}$ the slope parameter for mean annual

246 precipitation. The errors were considered to be i.i.d. as $\varepsilon_{i, t} \sim N\left(0, \sigma^{2}\right)$, with a general correlation

247 structure for the within-tree residuals. The parameter estimates indicate that aspen experienced 
248 greater $\delta^{13} \mathrm{C}$ values than spruce at very large or $0 \mathrm{~m} \mathrm{DTW}$ and no annual precipitation $\left(\beta_{1}\right.$ and $\beta_{2}$

249 in Table 3). However, $\delta^{13} \mathrm{C}$ was lower for aspen than spruce at average and high levels of

250 precipitation since the slope of MAP was more negative for aspen than spruce $\left(\beta_{4}\right.$ in Table 3$)$.

251 The relationship between $\delta^{13} \mathrm{C}$ and DTW was steeper for aspen, while a gradual change in $\delta^{13} \mathrm{C}$

252 with DTW was observed in the case of spruce $\left(\beta_{3}\right.$ in Table 3$)$. The plateau was reached at DTW

253 around $0.4 \mathrm{~m}$ for aspen and $7-8 \mathrm{~m}$ for spruce, but these values cannot be directly compared

254 since different flow initiation areas were used to calculate DTW for each species (Fig. 5). Since

255 these two models were fit using the method of maximum likelihood, we calculated a generalized

256 coefficient of determination $\left(\overline{\mathrm{R}}_{\mathrm{LR}}^{2}\right)$ using the likelihood ratio of the candidate model with the null

257 model (Cox and Snell 1989; Nagelkerke 1991). The $\delta^{13} \mathrm{C}$ model for aspen yielded a $\overline{\mathrm{R}}_{\mathrm{LR}}^{2}$ value of

258 0.72, whereas the model for spruce had a lower $\overline{\mathrm{R}}_{\mathrm{LR}}^{2}$ of 0.44 . The residual plots showed a lack of

259 systematic bias, while the Shapiro-Wilk test indicated that the normality assumption was met for

260 both models (Fig. 5).

\section{Tree size and the depth-to-water index}

Tree height was more strongly related with DTW than diameter at breast height for both

263 aspen and spruce (Eq. 1, Table 2). Height and diameter of spruce showed stronger relationships

264 with DTW (i.e., $\mathrm{R}^{2}$ of 0.56 and 0.41 , respectively) than was the case for aspen (i.e., $\mathrm{R}^{2}$ of 0.27

265 and 0.16 , respectively). Similarly to $\delta^{13} \mathrm{C}$, flow initiation areas of 1 ha for aspen and 16 ha for

266 spruce provided the strongest relationship for height of both species (Table 2). Although

267 diameter of aspen was more strongly related with DTW calculated at 2 ha (Table 2), because the

268 difference was small, we used the model with DTW calculated at 1 ha. Aspen were taller than

269 spruce, with a narrower range of heights from low DTW $(b=10.4 \mathrm{~m})$ to high DTW conditions ( $a$ 
$270=12.4 \mathrm{~m}$ ), whereas spruce trees varied from $4.3 \mathrm{~m}$ at low DTW to $8.9 \mathrm{~m}$ at large DTW. Tree

271 height became independent of DTW when DTW values exceeded $0.9 \mathrm{~m}$ for aspen and $11 \mathrm{~m}$ for

272 spruce (Fig. 6). Diameter of aspen trees was smaller than that of the spruce trees, and quickly

273 increased with DTW from $8.1 \mathrm{~cm}$ to $9.9 \mathrm{~cm}$ at DTW $>0.4 \mathrm{~m}$. In the case of spruce, diameter

274 increased more gradually from $8.9 \mathrm{~cm}$ at low DTW to $16.6 \mathrm{~cm}$ at DTW $>25 \mathrm{~m}$. Tree height was

275 estimated more tightly with standard error of about $1 \mathrm{~m}$, whereas diameter estimates had a

276 standard error of up to $2.5 \mathrm{~cm}$ in the case of spruce. Flow accumulation was not associated with

277 height or diameter of either species, whereas slope was positively related with height of the

278 spruce trees with a slope of $0.05(P=0.0196)$.

\section{Discussion}

\section{Topography and precipitation}

The model described by Eq. 3 incorporates both a topographic index and a climate

282 variable to explain variation in carbon isotope ratio of trembling aspen and white spruce. As

283 expected, the largest $\delta^{13} \mathrm{C}$ values are found in areas with high DTW and periods with low annual

284 precipitation (Fig. 5). Leavitt and Long (1986) suggest that a high resolution topographic index

285 that reflects site conditions could account for about 2 and $3 \%$ of the variation in $\delta^{13} \mathrm{C}$ between

286 trees. The relationship between $\delta^{13} \mathrm{C}$ and DTW is positive up to certain thresholds after which it

287 levels off (Fig. 4). An effect of topography on $\delta^{13} \mathrm{C}$ was also found by Garten and Taylor (1992),

288 who reported that foliar $\delta^{13} \mathrm{C}$ was higher for deciduous trees growing on drier areas (i.e., ridges

289 and slopes) than for those from wetter conditions (i.e., riparian). Similarly, more positive $\delta^{13} \mathrm{C}$

290 values were reported for leaves of broadleaved species growing on ridges than for those found in

291 the valley (Hanba et al. 2000). 
293 and 0.16 for spruce) since $\delta^{13} \mathrm{C}$ enrichment can be influenced by a range of environmental

294 factors as well as genotypic variation between trees. Weak relationships with DTW may also

295 occur because the DTW index does not completely or accurately integrate all site conditions

296 influencing availability of soil moisture, stomatal conductance and carbon fixation.

297 Photosynthesis is dependent on the amount of radiation intercepted by the leaf, thus increasing

298 light availability can lead to higher carbon demand which can also result in larger $\delta^{13} \mathrm{C}$ values

299 (Sohn et al. 2013; Warren et al. 2001). Larger $\delta^{13} \mathrm{C}$ values were also reported for mature aspen

300 trees that had been left standing after variable retention harvesting as a result of sudden exposure

301 to full sunlight, which led to higher evaporative demand and water stress (Bladon et al. 2007).

302 An effect of shading was found in our dataset, but we removed trees receiving more radiation

303 (i.e., edge and open grown trees) since they had higher $\delta^{13} \mathrm{C}$ values than the trees growing in

304 closed canopy stands. Furthermore, mineral nutrition can have strong influences on carbon

305 assimilation and $\delta^{13} \mathrm{C}$ (Francey and Farquhar 1982), as shown for $\delta^{13} \mathrm{C}$ in wood of Tsuga

306 heterophylla (Raf.) Sarg. (Walia et al. 2010). A proportion of the unexplained variation in $\delta^{13} \mathrm{C}$

307 might also be the result of inherited differences between trees, as indicated by a study that found

308 high heritability of $\delta^{13} \mathrm{C}$ (i.e., 0.54 compared to 0.39 for height) in Picea mariana (Mill.) BSP

309 (Johnsen et al. 1999).

Although topography influences water movement, several other studies have reported

311 that topography was not related with $\delta^{13} \mathrm{C}$. Topographic position did not have an effect on $\delta^{13} \mathrm{C}$

312 in tree rings of Sequoia sempervirens D. Don growing in an area with homogeneous terrain

313 morphology (Roden et al. 2011), while the effect of topography on $\delta^{13} \mathrm{C}$ was masked by the

314 ability of Pinus ponderosa Dougl. ex Laws. trees to access deep water sources and reduce water 
315 stress (Adams et al. 2014). Thus, topographic effects on $\delta^{13} \mathrm{C}$ might be inhibited by

316 redistribution of water taken up from deep soil layers or adjacent wet areas through tree roots and

317 root grafts (Burgess et al. 1998). Water redistribution among trees in clonal aspen stands (Brown

318 et al. 2014) may also reduce the magnitude as well as the occurrence of drought stress.

319 The negative relationship between $\delta^{13} \mathrm{C}$ and mean annual precipitation suggests that trees

320 experienced less stress during periods of higher precipitation (Fig. 3). A strong influence of

321 precipitation as well as air temperature on the seasonal pattern of $\delta^{13} \mathrm{C}$ was found in semi-arid

322 ecosystems with an aspen component in Utah (Buchmann et al. 1997). A similar effect of water

323 availability was found for 50 tree species growing along a rainfall gradient in northern Australia

324 (Schulze et al. 1998). Our analysis used time periods corresponding to wet-dry episodes and does

325 not allow us to explore the seasonality of the isotopic signal and the climate factors controlling

326 stomatal conductance. The DTW topographic index could be used to delineate the most and least

327 drought prone areas during years with low amounts of precipitation, and could also help explain

328 the spatial variability in drought related mortality in the boreal forest (Hogg et al. 2008).

329 Optimal flow initiation area

330 Flow initiation area controls the extent of the flow channel network used to calculate the

331 DTW raster. Using a small flow initiation area extends flow channels farther into the headwaters

332 of the watershed creating an extensive network of flow channels, which results in generally

333 lower DTW values. On the other hand, only major channels are identified when large flow

334 initiation areas are used. Our results show that selection of optimal flow initiation area depends

335 on topography of the study area. The relatively flat (i.e., slope of $2.5 \%$ ) topography of the

336 Grande Prairie site was better captured with a smaller flow initiation area (i.e., 1 ha), whereas the 
337 Whitecourt site with a more pronounced topography (i.e., 10.9\% slope) was more strongly

338 represented by larger flow initiation areas (i.e., 12 or 16 ha). These findings are consistent with a

339 study from Sweden that also emphasized the importance of substrate permeability, since it

340 controls drainage rate of water (Ågren et al. 2014).

341 Tree size and topography

342 Tree height varied more widely at the spruce site since the northern part of that area (i.e.,

343 shown in dark blue in Fig. 1) was covered by a bog where trees were shorter. Tree height was

344 more strongly related to DTW than diameter since diameter increment is affected by stand

345 structure to a greater extent than elongation of the terminal shoot (Oliver and Larson 1996). The

346 stronger relationship between height and DTW in spruce might be explained by the stronger

347 topographic gradients at the Whitecourt site, exerting a greater influence on soil attributes. The

348 relationship between tree size and DTW followed a similar pattern to that found for $\delta^{13} \mathrm{C}$,

349 suggesting that tree size does not increase with DTW after a certain DTW value. Other authors

350 reported weak to no relationships between tree size and other topographic indices which may

351 result from the coarse resolution (i.e., $30-35 \mathrm{~m}$ ) DEM used to calculate TWI (Byun et al. 2013;

352 Ehara et al. 2009). Conceptually, height of both species should reach a maximum value at

353 intermediate levels of DTW, and decline with either increasing or decreasing DTW (Wang and

354 Klinka 1996). Testing DTW with a wider range of tree ages and sizes could provide further

355 information on the pattern and nature of the relationship.

\section{$356 \quad$ Conclusions}

357 This study presents a model that uses information at two scales, small-scale through a 
358 topographic index and large-scale through a climate variable, to explain variation in carbon

359 isotope discrimination as a measure of tree physiological activity. More importantly, our results

360 validate the DTW index as a tool that can provide information about the status of individual

361 trees, particularly the effects of water availability in the soil. Results also highlight the

362 importance of choosing flow initiation areas that are appropriate to local site characteristics to

363 permit accurate representation of site properties through the DTW index. Tree height can be

364 measured from LiDAR point clouds or estimated using empirical models, but the model

365 presented here implies a functional relationship of tree height with a terrain attribute that

366 captures site conditions controlling tree growth. This opens the way for future studies that can

367 evaluate the potential to use the DTW index as predictor of stand-level properties, especially site

368 productivity with possible linkages to forecasting impacts of drought induced by climate change.

\section{Acknowledgements}

We would like to thank Ivan Bjelanovic, Valerie Krebs and Vlad Strimbu for assistance

371 with tree core collection in the field, Shujie Ren for granting access to laboratory supplies, Allan

372 Harms for performing the carbon isotope analyses, and Jae Ogilvie of the University of New

373 Brunswick for providing the geospatial data. This study was funded by Alberta Agriculture and

374 Forestry. We gratefully acknowledge the valuable comments provided by our reviewers.

\section{References}

375 Adams, H.R., Barnard, H.R., and Loomis, A.K. 2014. Topography alters tree growth-climate

376 relationships in a semi-arid forested catchment. Ecosphere 5. doi: 10.1890/es 14-00296.1. 
377 Ågren, A.M., Lidberg, W., Strömgren, M., Ogilvie, J., and Arp, P.A. 2014. Evaluating digital 378 terrain indices for soil wetness mapping - a Swedish case study. Hydrol. Earth Syst. Sci. 18: 379 3623-3634. doi: 10.5194/hess-18-3623-2014.

380 Allen, R.B., Peet, R.K., and Baker, W.L. 1991. Gradient analysis of latitudinal variation in 381 Southern Rocky Mountain forests. J. Biogeogr. 18: 123-139. doi: 10.2307/2845287.

382 Berry, J.A. 1988. Studies of mechanisms affecting the fractionation of carbon isotopes in 383 photosynthesis. In Stable isotopes in ecological research. Edited by P.W. Rundel, J. R. Ehleringer 384 and K. A. Nagy. pp. 82-94.

385 Beven, K.J., and Kirkby, M.J. 1979. A physically based, variable contributing area model of 386 basin hydrology. Hydrol. Sci. Bul. 24: 43-69. doi: 10.1080/02626667909491834.

387 Bladon, K.D., Silins, U., Landhausser, S.M., Messier, C., and Lieffers, V.J. 2007. Carbon isotope 388 discrimination and water stress in trembling aspen following variable retention harvesting. Tree 389 Physiol. 27: 1065-1071.

390 Brown, S.M., Petrone, R.M., Chasmer, L., Mendoza, C., Lazerjan, M.S., Landhausser, S.M., 391 Silins, U., Leach, J., and Devito, K.J. 2014. Atmospheric and soil moisture controls on 392 evapotranspiration from above and within a Western Boreal Plain aspen forest. Hydrol. Process.

393 28: 4449-4462. doi: 10.1002/hyp.9879.

394 Brubaker, S.C., Jones, A.J., Lewis, D.T., and Frank, K. 1993. Soil properties associated with 395 landscape position. Soil Sci. Soc. Am. J. 57: 235-239.

396 Buchmann, N., Kao, W.Y., and Ehleringer, J. 1997. Influence of stand structure on carbon-13 of 
397 vegetation, soils, and canopy air within deciduous and evergreen forests in Utah, United States.

398 Oecologia 110: 109-119. doi: 10.1007/s004420050139.

399 Burgess, S.S.O., Adams, M.A., Turner, N.C., and Ong, C.K. 1998. The redistribution of soil

400 water by tree root systems. Oecologia 115: 306-311. doi: 10.1007/s004420050521.

401 Burt, T.P., and Butcher, D.P. 1985. Topographic controls of soil moisture distributions. J. Soil

402 Sci. 36: 469-486.

403 Byun, J.G., Lee, W.K., Kim, M., Kwak, D.A., Kwak, H., Park, T., Byun, W.H., Son, Y., Choi,

404 J.K., Lee, Y.J., Saborowski, J., Chung, D.J., and Jung, J.H. 2013. Radial growth response of

405 Pinus densiflora and Quercus spp. to topographic and climatic factors in South Korea. Journal of

406 Plant Ecology 6: 380-392. doi: 10.1093/jpe/rtt001.

407 Cox, D.R., and Snell, E.J. 1989. The analysis of binary data. 2nd ed. Chapman and Hall, London.

408 pp. 208-209.

409 Ehara, H., Matsue, K., Shuin, Y., Aizawa, M., and Ohkubo, T. 2009. Validity of height

410 estimation of Hinoki cypress using soil moisture indices based on the digital terrain model in

411 Utsunomiya University Forests at Funyu. Bul. Utsunomiya Univ. For.: 9-16.

412 Farquhar, G.D., Ehleringer, J.R., and Hubick, K.T. 1989. Carbon isotope discrimination and

413 photosyntehsis. Annu. Rev. Plant Physiol. Plant Molec. Biol. 40: 503-537. doi:

414 10.1146/annurev.arplant.40.1.503.

415 Farquhar, G.D., Oleary, M.H., and Berry, J.A. 1982. On the relationship between carbon isotope

416 discrimination and the inter-cellular carbon dioxide concentration in leaves. Aust. J. Plant 
417 Physiol. 9: 121-137.

418 Francey, R.J., and Farquhar, G.D. 1982. An explanation of 13C/12C variations in tree rings.

419 Nature 297: 28-31.

420 Garten, C.T., and Taylor, G.E. 1992. Foliar delta C-13 within a temperate deciduous forest -

421 spatial, temporal, and species sources of variation. Oecologia 90: 1-7. doi: 10.1007/bf00317801.

422 Guntner, A., Seibert, J., and Uhlenbrook, S. 2004. Modeling spatial patterns of saturated areas:

423 An evaluation of different terrain indices. Water Resour. Res. 40. doi: 10.1029/2003wr002864.

424 Hanba, Y.T., Noma, N., and Umeki, K. 2000. Relationship between leaf characteristics, tree

425 sizes and species distribution along a slope in a warm temperate forest. Ecological Research 15:

426 393-403. doi: 10.1046/j.1440-1703.2000.00360.x.

427 Hogg, E.H., Brandt, J.P., and Michaellian, M. 2008. Impacts of a regional drought on the 428 productivity, dieback, and biomass of western Canadian aspen forests. Can. J. For. Res. 38: 429 1373-1384. doi: 10.1139/x08-001.

430 Johnsen, K.H., Flanagan, L.B., Huber, D.A., and Major, J.E. 1999. Genetic variation in growth, 431 carbon isotope discrimination, and foliar N concentration in Picea mariana: analyses from a 432 half-diallel mating design using field-grown trees. Can. J. For. Res. 29: 1727-1735. doi:

433 10.1139/cjfr-29-11-1727.

434 Kopecky, M., and Cizkova, S. 2010. Using topographic wetness index in vegetation ecology:

435 does the algorithm matter? Appl. Veg. Sci. 13: 450-459. doi: 10.1111/j.1654-

436 109X.2010.01083.x. 
437 Leavitt, S.W. 1993. Seasonal C-13/C-12 changes in tree rings - species and site coherence, and a 438 possible drought influence. Can. J. For. Res. 23: 210-218. doi: 10.1139/x93-028.

439 Leavitt, S.W., and Long, A. 1984. Sampling strategy for stable carbon isotope analysis of tree $440 \quad$ rings in pine. Nature 311: 145-147. doi: 10.1038/311145a0.

441 Leavitt, S.W., and Long, A. 1986. Stable carbon isotope variability in tree foliage and wood.

442 Ecology 67: 1002-1010. doi: 10.2307/1939823.

443 MacCormack, K.E., Atkinson, N., and Lyster, S. 2015. Bedrock topography of Alberta, Canada. 444 Alberta Geological Survey, Edmonton, AB.

445 Monserud, R.A., and Marshall, J.D. 2001. Time-series analysis of delta C-13 from tree rings. I.

446 Time trends and autocorrelation. Tree Physiol. 21: 1087-1102.

447 Moore, I.D., Gessler, P.E., Nielsen, G.A., and Peterson, G.A. 1993. Soil attribute prediction 448 using terrain analysis. Soil Sci. Soc. Am. J. 57: 443-452. doi:

$449 \quad 10.2136 /$ sssaj1993.03615995005700020026x.

450 Moore, I.D., Grayson, R.B., and Ladson, A.R. 1991. Digital terrain modelling: a review of 451 hydrological, geomorphological, and biological applications. Hydrol. Process. 5: 3-30. doi: $452 \quad 10.1002 /$ hyp.3360050103.

453 Murphy, P.N.C., Ogilvie, J., and Arp, P. 2009. Topographic modelling of soil moisture 454 conditions: a comparison and verification of two models. Eur. J. Soil Sci. 60: 94-109. doi: $455 \quad 10.1111 / \mathrm{j} .1365-2389.2008 .01094 . x$.

456 Murphy, P.N.C., Ogilvie, J., Connor, K., and Arpl, P.A. 2007. Mapping wetlands: A comparison 
457 of two different approaches for New Brunswick, Canada. Wetlands 27: 846-854. doi:

$458 \quad 10.1672 / 0277-5212(2007) 27[846:$ mwacot $] 2.0 . \operatorname{co} ; 2$.

459 Murphy, P.N.C., Ogilvie, J., Meng, F.R., White, B., Bhatti, J.S., and Arp, P.A. 2011. Modelling

460 and mapping topographic variations in forest soils at high resolution: A case study. Ecol. Model.

$461 \quad$ 222: 2314-2332. doi: 10.1016/j.ecolmodel.2011.01.003.

462 Nagelkerke, N.J.D. 1991. A note on a general definition of the coefficient of determination.

463 Biometrika 78: 691-692. doi: 10.1093/biomet/78.3.691.

464 O'Callaghan, J.F., and Mark, D.M. 1984. The extraction of drainage networks from digital

465 elevation data. Comput. Vision Graph. 28: 323-344. doi: 10.1016/s0734-189x(84)80011-0.

466 Oliver, C.D., and Larson, B.C. 1996. Forest stand dynamics. Update edition ed. John Wiley \&

467 Sons, Inc., New York.

468 Oltean, G.S., Comeau, P.G., and White, B. 2016. Linking the Depth-to-Water Topographic Index 469 to Soil Moisture on Boreal Forest Sites in Alberta. For. Sci. 62: 12. doi:

470 http://dx.doi.org/10.5849/forsci.15-054.

471 Pinheiro, J.C., and Bates, D.M. 1995. Model building for nonlinear mixed-effects models.

472 University of Wisconsin-Madison. 91.

473 Pinheiro, J.C., and Bates, D.M. 2000. Mixed-effects models in S and S-PLUS. Springer-Verlag,

474 New York, NY. pp. 57-96; 201-225; 305-336.

475 Pinheiro, J.C., Bates, D.M., DebRoy, S., Sarkar, D., and Team, R.C. 2015. nlme: Linear and

476 nonlinear mixed effects models. In http://CRAN.R-project.org/package=nlme. 
477 R Core Team. 2015. R: A language and environment for statistical computing. R Foundation for 478 Statistical Computing, Vienna, Austria.

479 Roden, J.S., Johnstone, J.A., and Dawson, T.E. 2011. Regional and watershed-scale coherence in 480 the stable-oxygen and cabon isotope ratio time series in tree rings of coast redwood (Sequoia 481 sempervirens). Tree-Ring Research 67: 71-86.

482 Schulze, E.D., Williams, R.J., Farquhar, G.D., Schulze, W., Langridge, J., Miller, J.M., and 483 Walker, B.H. 1998. Carbon and nitrogen isotope discrimination and nitrogen nutrition of trees 484 along a rainfall gradient in northern Australia. Aust. J. Plant Physiol. 25: 413-425.

485 Seibert, J., Stendahl, J., and Sorensen, R. 2007. Topographical influences on soil properties in 486 boreal forests. Geoderma 141: 139-148. doi: 10.1016/j.geoderma.2007.05.013.

487 Sohn, J.A., Gebhardt, T., Ammer, C., Bauhus, J., Haeberle, K.-H., Matyssek, R., and Grams, 488 T.E.E. 2013. Mitigation of drought by thinning: Short-term and long-term effects on growth and 489 physiological performance of Norway spruce (Picea abies). For. Ecol. Manag. 308: 188-197. doi: $490 \quad 10.1016 /$ j.foreco.2013.07.048.

491 Sorensen, R., Zinko, U., and Seibert, J. 2006. On the calculation of the topographic wetness 492 index: evaluation of different methods based on field observations. Hydrol. Earth Syst. Sci. 10: $493 \quad 101-112$.

494 Tarboton, D.G. 1997. A new method for the determination of flow directions and upslope areas 495 in grid digital elevation models. Water Resour. Res. 33: 309-319. doi: 10.1029/96wr03137.

496 Walia, A., Guy, R.D., and White, B. 2010. Carbon isotope discrimination in western hemlock 
497 and its relationship to mineral nutrition and growth. Tree Physiol. 30: 728-740. doi:

$498 \quad 10.1093 /$ treephys/tpq020.

499 Wang, G.G., and Klinka, K. 1996. Use of synoptic variables in predicting white spruce site 500 index. For. Ecol. Manag. 80: 95-105. doi: 10.1016/0378-1127(95)03630-x.

501 Waring, R.H., and Silvester, W.B. 1994. Variation in foliar delta C-13 values within the crowns 502 of Pinus radiata trees. Tree Physiol. 14: 1203-1213.

503 Warren, C.R., McGrath, J.F., and Adams, M.A. 2001. Water availability and carbon isotope 504 discrimination in conifers. Oecologia 127: 476-486. doi: 10.1007/s004420000609.

505 White, B., Ogilvie, J., Campbell, D.M.H., Hiltz, D., Gauthier, B., Chisholm, H.K., Wen, H.K., 506 Murphy, P.N.C., and Arp, P.A. 2012. Using the cartographic depth-to-water index to locate small 507 streams and associated wet areas across landscapes. Can. Water Resour. J. 37: 333-347. doi: 508 10.4296/cwrj2011-909. 
https://mc06.manuscriptcentral.com/cjfr-pubs 
Table 1. Geographic location, topography and climate at the two study sites where trembling aspen and white spruce trees were sampled for carbon isotope analyses. DBH - diameter at breast height, MAT - mean annual temperature, MAP - mean annual precipitation.

\begin{tabular}{lrr}
\hline & Grande Prairie & Whitecourt \\
\hline Species & trembling aspen & white spruce \\
Number of trees & 42 & 43 \\
Height $(\mathrm{m})$ & 11.5 & 8.2 \\
Height range $(\mathrm{m})$ & $8.8-14.2$ & $4.7-10.3$ \\
Diameter $(\mathrm{cm})$ & 9.5 & 13.7 \\
DBH range $(\mathrm{cm})$ & $6.8-12.4$ & $6.5-19.5$ \\
Latitude $\left({ }^{\circ} \mathrm{N}\right)$ & 54.9099 & 54.1198 \\
Longitude $\left({ }^{\circ} \mathrm{W}\right)$ & 118.9251 & 115.9269 \\
Elevation $(\mathrm{m})$ & 711.8 & 839.7 \\
Slope $(\%)$ & 2.5 & 10.9 \\
MAT $^{*}\left({ }^{\circ} \mathrm{C}\right)$ & 2.2 & 2.9 \\
MAP* $(\mathrm{mm} / \mathrm{yr})$ & 445.1 & 544.4 \\
Weather Canada & Grande Prairie A & Whitecourt A \\
station &
\end{tabular}

* extracted from "1981-2010 Canadian Climate Normals available online at http://climate.weather.gc.ca accessed on August 27, 2014 
Table 2. Coefficients of determination $\left(\mathrm{R}^{2}\right)$ shown for the regression models between the topographic indices and the conditional modes $\left(b_{i}\right)$ of the random effects in Eq. 2, height, and diameter of the trembling aspen and white spruce trees. The asymptotic function in Eq. 1 was used for the models with the depth-to-water index as predictor, and simple linear regression for flow accumulation (FA) and slope.

\begin{tabular}{|c|c|c|c|c|c|c|c|c|c|c|}
\hline & \multirow{2}{*}{$\mathrm{R}^{2}$} & \multicolumn{7}{|c|}{ Flow initiation area used to calculate the depth-to-water index } & \multirow{2}{*}{$\log _{10}(\mathrm{FA})$} & \multirow{2}{*}{ Slope } \\
\hline & & $0.5 \mathrm{ha}$ & 1 ha & 2 ha & 4 ha & 8 ha & 12 ha & 16 ha & & \\
\hline \multirow{3}{*}{$\begin{array}{l}\text { Trembling } \\
\text { aspen }\end{array}$} & $b_{i}\left(\delta^{13} C\right)$ & 0.176 & 0.419 & 0.296 & 0.143 & 0.107 & 0.107 & 0.107 & 0.008 & 0.047 \\
\hline & height & 0.148 & 0.272 & 0.235 & 0.187 & 0.059 & 0.060 & 0.060 & 0.001 & 0.000 \\
\hline & diameter & 0.088 & 0.119 & 0.158 & 0.002 & 0.016 & 0.017 & 0.017 & 0.000 & 0.019 \\
\hline \multirow{3}{*}{$\begin{array}{l}\text { White } \\
\text { spruce }\end{array}$} & $b_{i}\left(\delta^{13} C\right)$ & 0.002 & 0.028 & 0.108 & 0.063 & 0.139 & 0.158 & 0.160 & 0.035 & 0.003 \\
\hline & height & 0.129 & 0.277 & 0.393 & 0.278 & 0.362 & 0.546 & 0.563 & 0.018 & 0.126 \\
\hline & diameter & 0.088 & 0.226 & 0.161 & 0.139 & 0.208 & 0.410 & 0.414 & 0.002 & 0.046 \\
\hline
\end{tabular}


Table 3. Parameter estimates and $95 \%$ confidence intervals (CI) for the models (Eq. 3) of carbon isotope ratio $\left(\delta^{13} \mathrm{C}\right)$ in wood tissue of trembling aspen and white spruce as a function of depth-towater (DTW) and mean annual precipitation (MAP). DTW was calculated a flow initiation area of 1 ha for aspen and 16 ha for spruce. The generalized coefficient of determination $\left(\overline{\mathrm{R}}_{\mathrm{LR}}^{2}\right)$ is shown for both models.

\begin{tabular}{|c|c|c|c|c|c|}
\hline & \multicolumn{4}{|c|}{ Parameters in Eq. 3} & \multirow{2}{*}{$\begin{array}{l}\text { Residual SD } \\
\qquad(\sigma)\end{array}$} \\
\hline & $\beta_{1}$ (asymptote) & $\beta_{2}(=y(0,0))$ & $\beta_{3}(\mathrm{DTW})$ & $\beta_{4}(\mathrm{MAP})$ & \\
\hline \multicolumn{6}{|c|}{ Trembling aspen $\left(\overline{\mathrm{R}}_{\mathrm{LR}}^{2}=0.72\right)$} \\
\hline $\begin{array}{l}\text { Estimated } \\
\text { parameter } \\
(95 \% \mathrm{CI})\end{array}$ & $\begin{array}{c}-23.997 \\
(-24.349--23.645)\end{array}$ & $\begin{array}{c}-25.740 \\
(-27.160--24.321)\end{array}$ & $\begin{array}{c}2.305 \\
(1.261-3.350)\end{array}$ & $\begin{array}{c}-0.0054 \\
(-0.0061--0.0047)\end{array}$ & $\begin{array}{c}0.505 \\
(0.424-0.603)\end{array}$ \\
\hline \multicolumn{6}{|c|}{ White spruce $\left(\overline{\mathrm{R}}_{\mathrm{LR}}^{2}=0.44\right)$} \\
\hline $\begin{array}{l}\text { Estimated } \\
\text { parameter } \\
(95 \% \mathrm{CI})\end{array}$ & $\begin{array}{c}-25.265 \\
(-26.236--24.295)\end{array}$ & $\begin{array}{c}-26.187 \\
(-27.267--25.106)\end{array}$ & $\begin{array}{c}-1.795 \\
(-5.105-1.515)\end{array}$ & $\begin{array}{c}-0.0010 \\
(-0.0018--0.0002)\end{array}$ & $\begin{array}{c}0.733 \\
(0.604-0.890)\end{array}$ \\
\hline
\end{tabular}



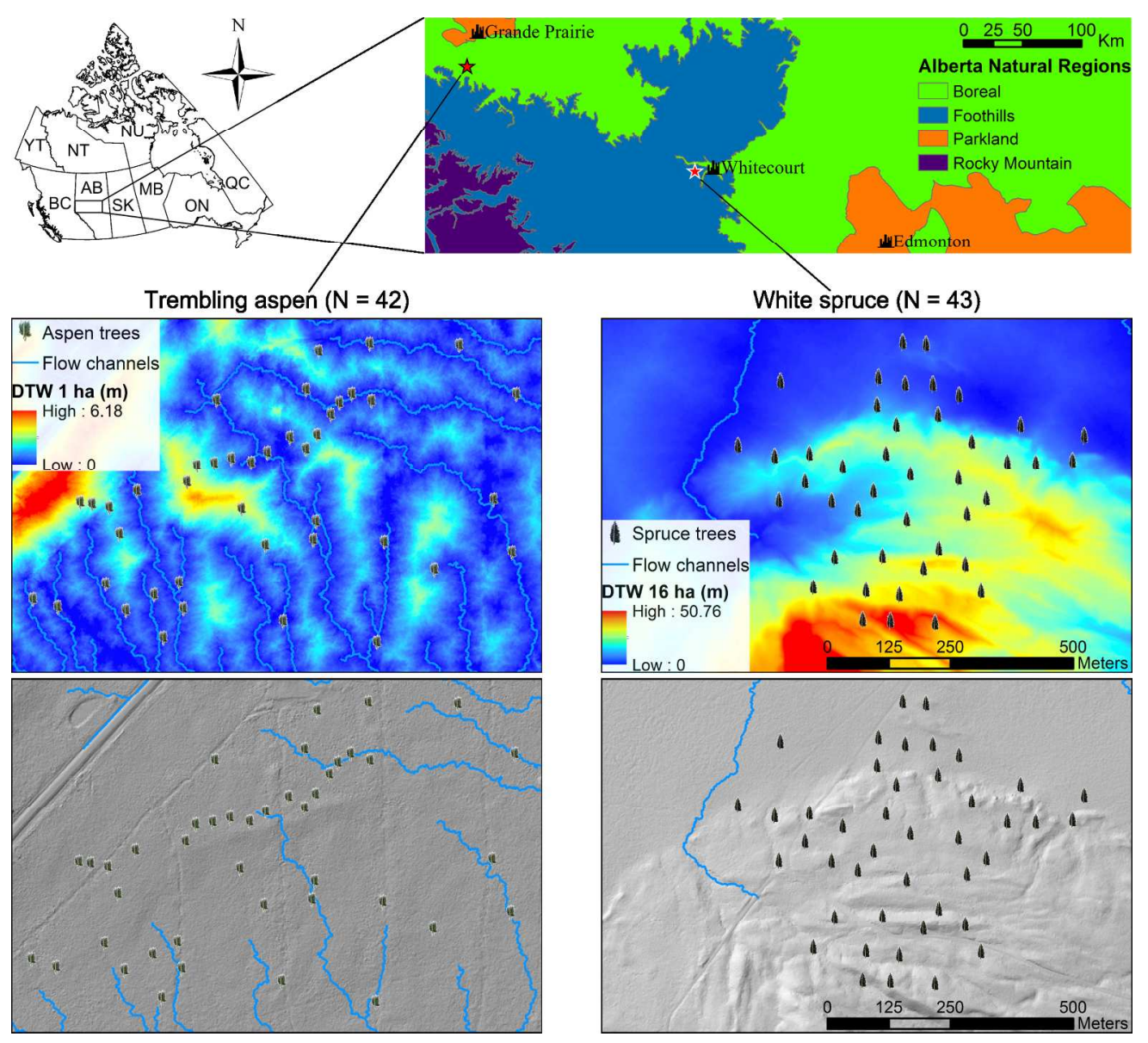

Location of the two study sites in the Boreal Mixedwoods and Foothills ecoregions of Alberta, Canada, from where trembling aspen and white spruce trees were selected (points). The hillshade images (lower panels) show the contrasting topography between the two sites, which controls the flow channel delineation and depth-to-water (DTW) raster calculation (upper panels). Note that DTW was calculated at a flow initiation area of 1 ha for the aspen site and 16 ha for the spruce site. 


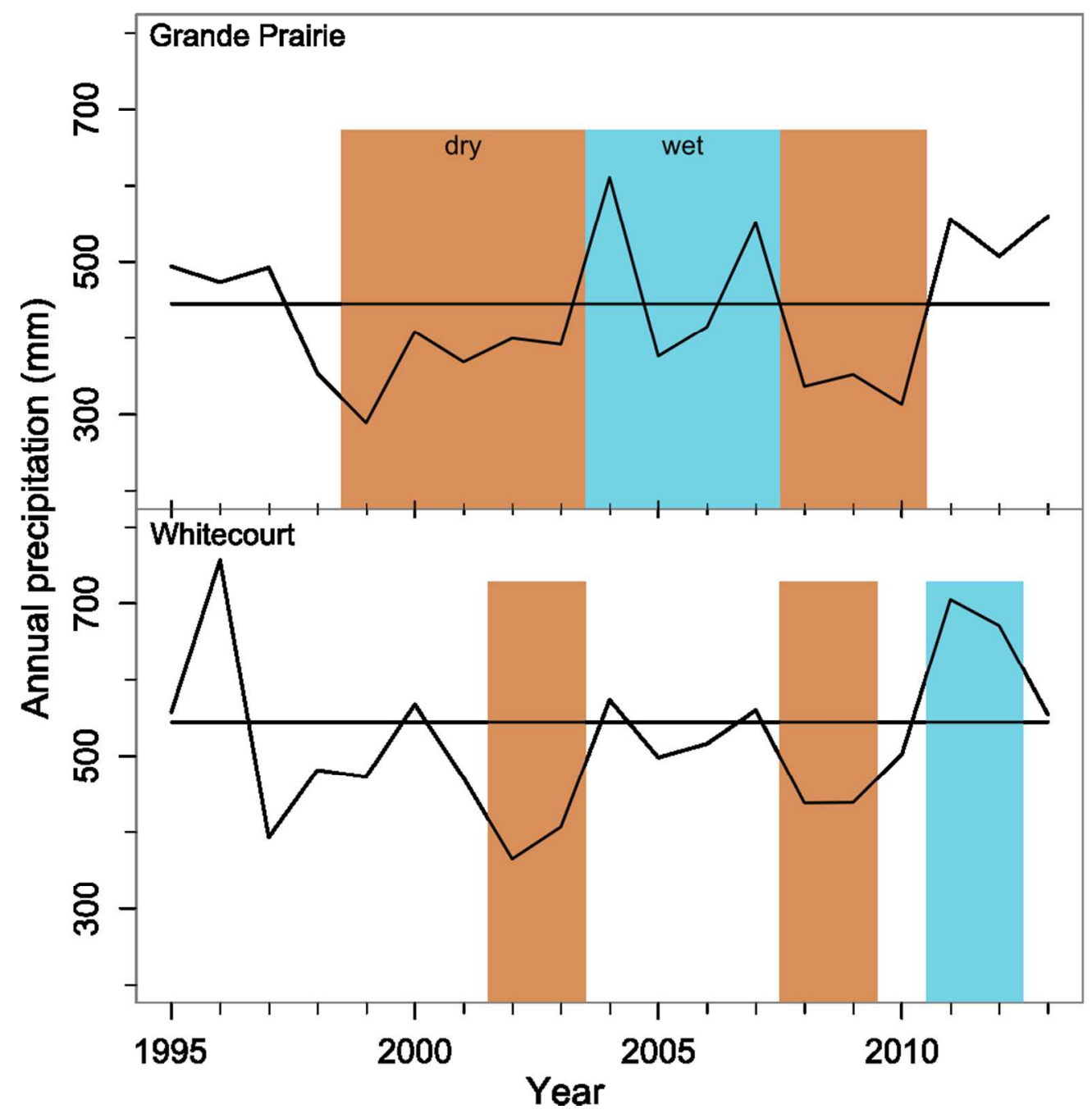

Annual precipitation and 30-year (1981-2010) normals (flat line) at the Grande Prairie (aspen) and Whitecourt (spruce) study sites from 1995 to 2013. The selected periods for carbon isotope analysis are shaded in the darker brown color if precipitation was less than normal (i.e., dry) and lighter blue if it exceeded normal values (i.e., wet). 


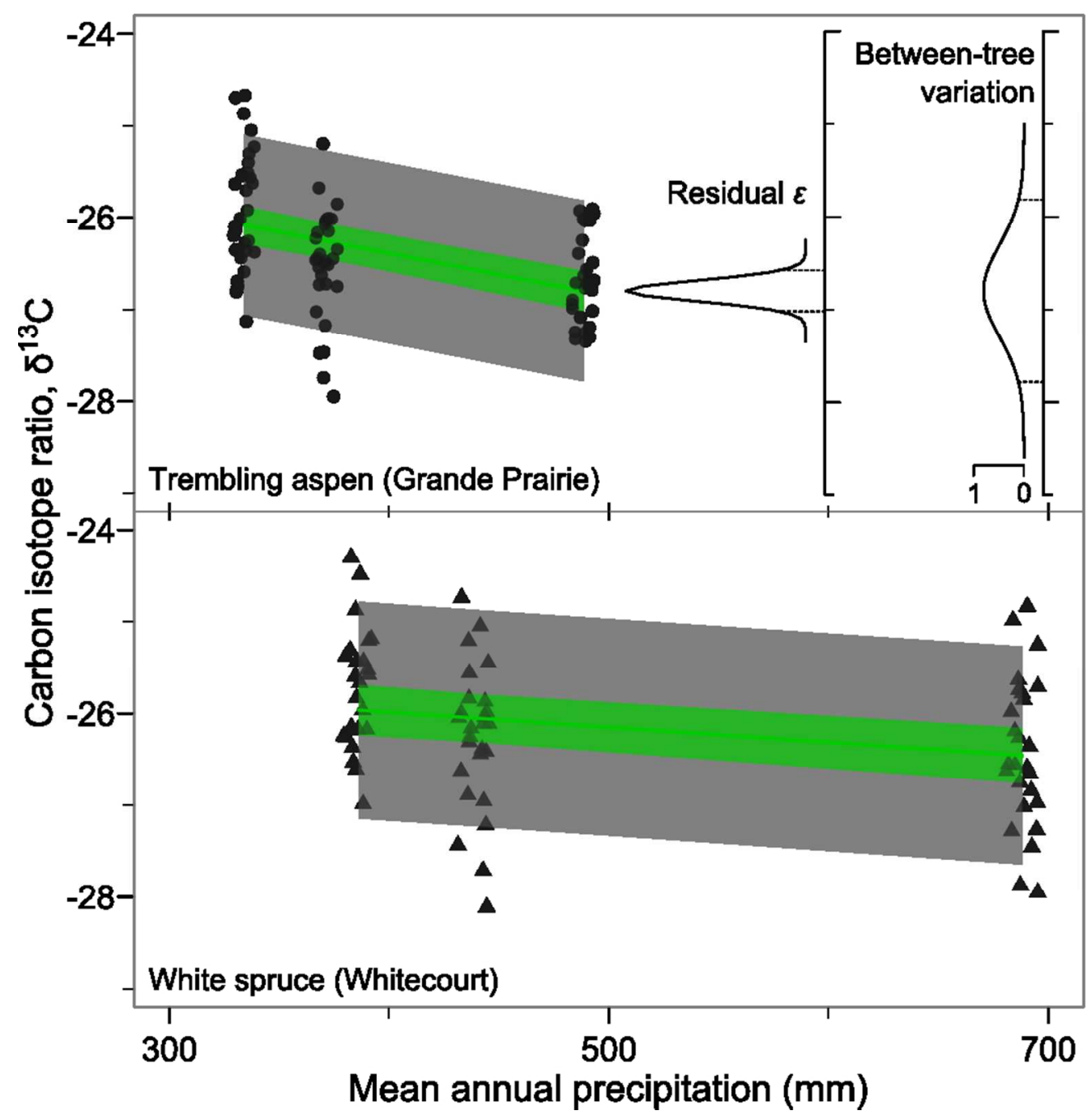

Carbon isotope ratio in woody tissue of trembling aspen and white spruce decreased with mean annual precipitation. The darker green shading shows the $95 \%$ confidence band for the linear mixed-effects model in Eq. 2 while the lighter gray shows the $95 \%$ confidence envelope including the intercept variance $\left(\sigma \_b \wedge 2\right)$. Note the greater variation between trees compared to the residual error. 


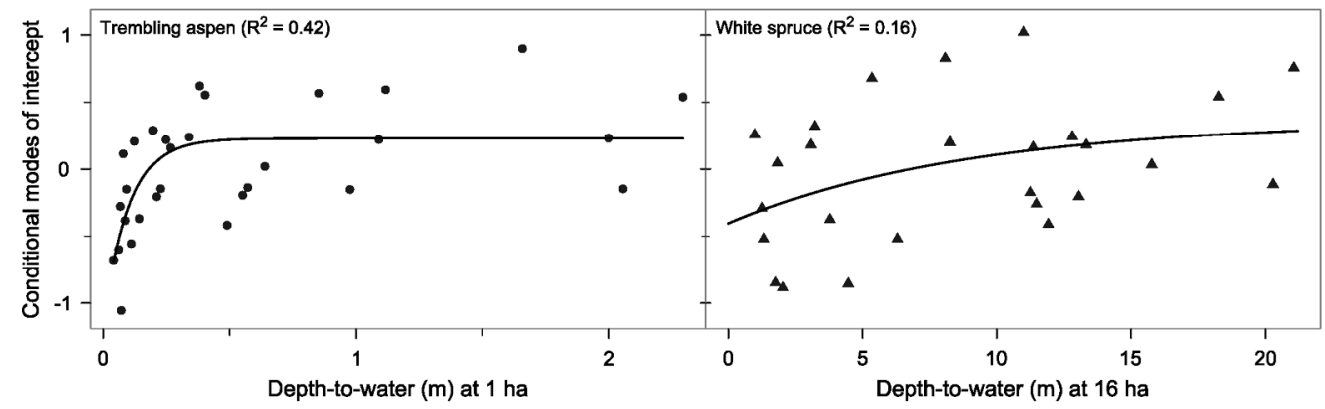

Fitted asymptotic (Eq. 1) regression between the conditional modes (bi) of the random effects in Eq. 2, representing the inter-tree variation in carbon isotope ratio, and depth-to-water calculated at a flow initiation area of 1 ha for trembling aspen and 16 ha for white spruce. 

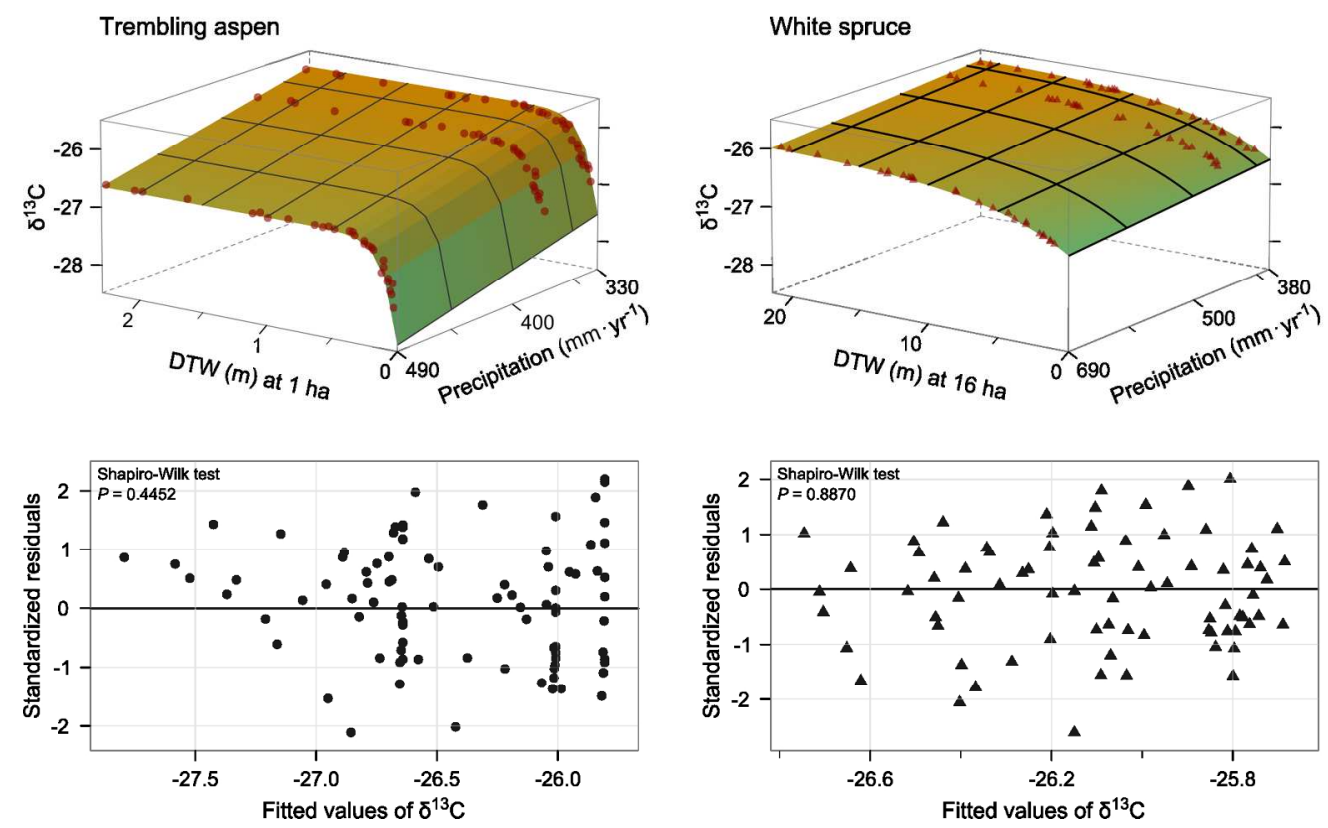

Carbon isotope ratio $\left(\delta^{\wedge} 13 \mathrm{C}\right)$ in wood tissue of trembling aspen and white spruce modeled as a function of depth-to-water (DTW) and mean annual precipitation (Eq. 3). DTW was calculated at a flow initiation area of 1 ha for aspen and 16 ha for spruce. The residual plots (bottom) and the Shapiro-Wilk test confirm the good fit of the model. Note that the points on the model surface are the fitted values. 

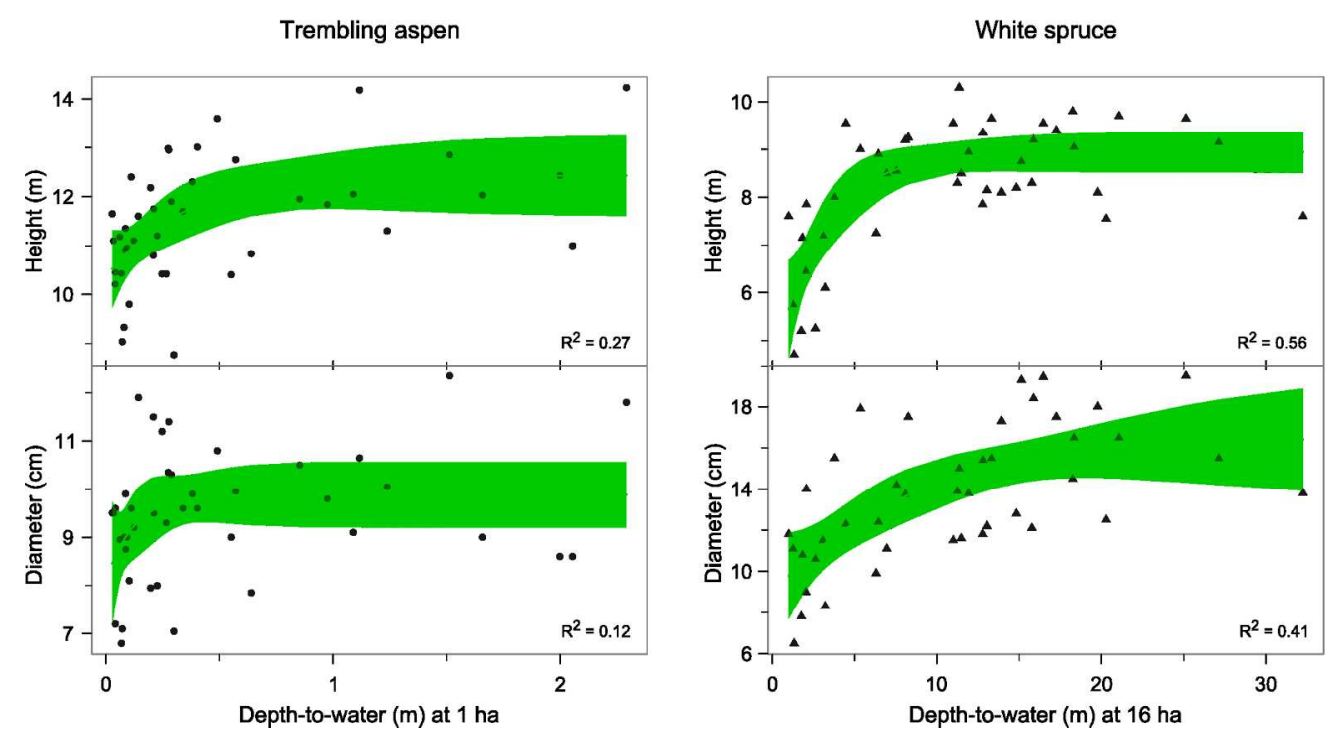

Fitted nonlinear regression (Eq. 1) and 95\% confidence envelope for tree height and diameter at breast height of trembling aspen and white spruce modeled as a function of depth-to-water, calculated at a flow initiation area of 1 ha for aspen and 16 ha for spruce. Note that the scale of the $y$-axis is not the same across panels. 